\title{
A History of Wine in America
}


This page intentionally left blank 


\section{A history OF WINE IN \\ AMERICA \\ From the Beginnings to Prohibition}

Thomas Pinney

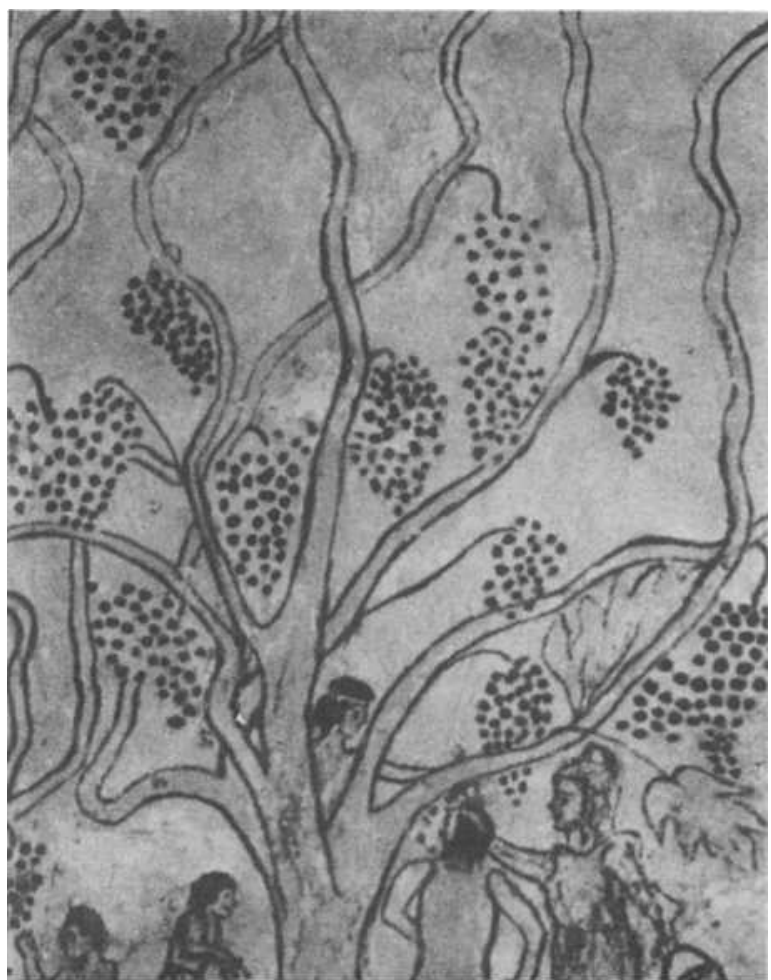

UNIVERSITY

OF

CALIFORNIA PRESS

Berkeley

Los Angeles London 
University of California Press

Berkeley and Los Angeles, California

University of California Press, Ltd.

London, England

First paperback printing 2007

(C) 1989 by The Regents of the University of California

\section{LIBRARY OF CONGRESS CATALOGING-IN-PUBLICATION DATA}

Pinney, Thomas.

A history of wine in America from the beginnings to Prohibition.

Includes index.

I. Wine and wine making-United States-History.

I. Title.

TP557.P56 $1989 \quad 663^{\prime} .2^{\prime} 00973 \quad$ 88-10798

ISBN 978-0-520-25429-9 (pbk: alk.)

Printed in the United States of America

$\begin{array}{lllllllll}15 & 14 & 13 & \text { I2 } & \text { II } & \text { I0 } & 09 & 08 & 07\end{array}$

$\begin{array}{llllllll}9 & 8 & 7 & 6 & 5 & 4 & 3 & 2\end{array}$

Natures Book contains $50 \%$ post-consumer waste and meets the minimum requirements of ANsI/NISO Z39.48-1992 (R 1997) (Permanence of Paper). () 
To my wife,

Sherrill Ohman Pinney

olim legendum 
This page intentionally left blank 